\title{
O ABANDONO AFETIVO E AS FRONTEIRAS DA INTERVENÇÃO ESTATAL NO ÂMBITO PRIVATISTICO DOS INDIVÍDUOS
}

\author{
AFFECTIVE ABANDONMENT AND THE BOUNDERIES OF STATE \\ INTERVENTIONISM IN PRIVATISM OF PERSONS
}

\author{
${ }^{1}$ Dirce Do Nascimento Pereira \\ ${ }^{2}$ Zilda Mara Consalter
}

\section{RESUMO}

Enquanto os laços biológicos preponderavam, as questões jurídicas do universo familiar eram razoavelmente simples. Diante da transformação do cenário familiar, destacando-se o afeto como alicerce da construção e reinvenção das relações, não há como conceber que apenas o amparo material seja suficiente; fator que gera entre os seus membros a responsabilidade pelo descumprimento do dever jurídico da assistência moral, emocional e psicológica. Assim, esta investigação objetiva demonstrar a transformação do pensamento jurídico quanto à afetividade, evidenciando tanto as novas responsabilidades no âmbito familiar quanto na esfera estatal, sugerindo-se certa limitação à atuação deste quanto a alguns aspectos.

Palavras-chave: Afetividade, Abandono afetivo, Intervenção estatal, Limites

\begin{abstract}
While the biological bonds were preponderant, legal issues related to family were fairly simple. With the transformation of the family these days, when the affective ties come as foundation of the construction and reinvention of relations, there is no how to assume that only financial support is sufficient; this factor generates among its members the responsibility for violation of legal duty of moral, emotional and psychological assistance. Thus, this investigation aims demonstrate the transformation of legal thought related to affectivity, showing new responsibilities in family ambit and by State, as well suggesting limitations to its performance related to some aspects.
\end{abstract}

Keywords: Affection, Affective abandonment, State interventionism, Limits

\footnotetext{
${ }^{1}$ Mestra em Direito pela Pontifícia Universidade Católica do Paraná - PUC/PR, Paraná, PR, (Brasil). Professora na Universidade Estadual de Ponta Grossa - UEPG, Paraná, PR. E-mail: dircenpereira@ hotmail.com.

${ }^{2}$ Doutora em Direito Civil pela Faculdade de Direito do Largo de São Francisco - Universidade de São Paulo USP, São Paulo, SP. Professora da Universidade Estadual de Ponta Grossa, UEPG, Paraná, PR (Brasil). .E-mail: zilda_advocacia@hotmail.com.
} 


\section{INTRODUÇÃO}

A família é um objeto de estudo complexo. Fato. E todas as relações que compõem esse ambiente igualmente o são. Outro fato.

Assim sendo, o debruçar sobre os liames parentais não poderia ter outro jaez: é difícil e complicado compreender e estabelecer linhas que definam direitos e deveres, bônus e responsabilidades, legitimados e vítimas aferíveis nesses laços.

Evidentemente as relações materno e paterno-filiais não fogem a esta regra. No entanto, não é por esse motivo que não devam ser permanentemente avaliadas e suas consequências jurídicas estudadas, a fim de se montar um arcabouço teórico de qualidade sobre o tema.

Em respeito a essa permanente necessidade social e jurídica, e especialmente após o reconhecimento do afeto como "[...] o elemento distintivo da família, que a coloca sob o manto da juridicidade [...]" (DIAS, 2011, p. 40), sendo este considerado a base essencial de todas as relações familiares contemporâneas, é que se desenvolveu a investigação geradora desse ensaio.

Primeiramente há que se considerar que os laços consanguíneos não deixaram de caracterizar a origem do elo familiar. Todavia, não mais definem essa condição de modo definitivo. Esse papel, hoje, é mais marcante na figura do laço afetivo que do biológico.

Assim sendo, pelo viés epistêmico, a sustentação da investigação e resultados que ora se pretende demonstrar serão concretizados a partir do método dedutivo de abordagem científica, partindo-se da análise do princípio da afetividade como paradigma identificador dos novos arranjos familiares perpassando, então, pela avaliação do objetivo dever jurídico da assistência e solidariedade de seus membros para então se abordar, especificamente, o descumprimento desse dever, esculpido na figura jurídica do abandono afetivo e em quais medidas estão sendo tomadas do ponto de vista jurídico para mitigar os efeitos de sua prática.

No entanto, e relembrando a afirmação inicial deste texto, o grau de complexidade desta investigação faz com que se teça, ainda, uma análise crítica do papel do Estado nessa "quebra" do dever de assistência. Ou seja: até que ponto o ente público pode (ou deve) se imiscuir nas relações privadas?

Postas estas primeiras considerações, passa-se então à explanação dos resultados e à discussão dos mesmos, esperando-se que sejam linhas que suscitem profícua discussão e 
profunda meditação por parte de toda a comunidade jurídica.

\title{
2 MUTAÇÕES DA RELAÇÃO PARENTAL E A AFETIVIDADE COMO SEU PARADIGMA
}

A importância do escorço histórico que permeou a transformação da família - e principalmente da relação materno e paterno-filial - é significativa. No entanto, o enfoque que se busca nessas linhas é a caracterização do princípio da afetividade, atualmente considerado como elemento paradigmático das relações parentais, como fito de melhor se delinear o seu reverso, representado na figura abstrata do abandono afetivo.

Portanto, far-se-á uma abordagem situacional acerca de algumas das principais variantes em relação aos vínculos parentais presentes na organização familiar no decorrer dos tempos e, sequencialmente, entabular-se-á a necessária discussão sobre a afetividade como princípio e seu maior fundamento axiológico.

Em tempos remotos, a religião representava a maior força vinculativa presente entre os membros da família. Assim, quando havia o nascimento do filho proveniente da relação entre a mulher e o seu marido, este fato representava exclusivamente um laço físico, dependente da declaração de aceitação por parte do marido se esta criança pertenceria ou não à família. (FUSTEL DE COULANGES, 1998; ENGELS, 1991)

\begin{abstract}
O que une os membros da família antiga é algo mais potente do que o nascimento, o sentimento, a força física: é a religião do lar e dos antepassados. Ela faz que a família forme uma unidade nesta vida e na outra. A família antiga é uma associação religiosa, mais ainda do que uma associação natural. [...] Sem dúvida, não foi a religião que criou a família, mas certamente foi ela que lhe deu normas, e vem daí que a família antiga teve uma constituição tão diferente da que teria tido se os sentimentos naturais tivessem sido os únicos a fundamentá-la. (COULANGES, 1998, p. 37)
\end{abstract}

Como não havia preocupação com sentimento de bem-estar e convivência entre os integrantes do núcleo familiar ocorria o que se denominou como "asfixia do afeto", uma vez que o interesse predominante do marido estava fundado, além da religião a aspectos sociais, patrimoniais e econômicos, evidenciados a partir da celebração do casamento, que ocorria por meros critérios de conveniência e interesse. Nem mesmo o vínculo consanguíneo era prevalente aos demais nesta época. (BARROS, 2002, p. 7)

A função procracional também fazia parte deste cenário, porém correlacionada ao aspecto religioso e econômico sob a justificativa de que o aumento do número de filhos aumentava a reverência ao fogo sagrado, bem como a manutenção econômica dos integrantes da família. (COULANGES, 1998)

Com o decurso do tempo, a força da vinculação religiosa do medievo como pilar da estruturação das conformações familiares foi sendo substituída, em parte, pela vinculação 
puramente consanguínea e com efeitos políticos, momento em que a família passou a buscar no tado a concretização de seus interesses originariamente privados, especialmente o fortalecimento dos clãs. (GILISSEN, 1995, p. 614)

Além da evolução social, também o avanço da tecnologia representou fator preponderante para o declínio da forma de elo filial fundado na religião e nos demais fatores presentes durante a transformação da relação parental. No final do Século XX, entre outros avanços das ciências biológicas, surgiu a possibilidade de constatação da paternidade/maternidade pela análise do ácido desoxirribonucleico ( $\left(\mathrm{DNA}^{1}\right.$ ). O vínculo biológico passou a ser o principal fator de determinação da filiação. No Brasil, esta alternativa inovadora tem início a partir do ano de 1988, sendo que outros avanços também podem ser retratados como fundamentais nesse sentido, tais como a "invenção da pílula anticoncepcional e as invenções de diversas técnicas de reprodução assistida". (ROCHA, 2009. p. 185).

No entanto, no que se refere à identificação do vínculo parental a família não permaneceu estacionária; transformou-se significativamente, foi moldada pelas novas concepções sociais (passando a ser entendida como um fenômeno cultural) e inspirada nos princípios constitucionais da dignidade da pessoa humana, da igualdade dos filhos, da solidariedade familiar e, principalmente, da afetividade. (PEREIRA, 2015)

Atualmente, há um “deslocamento da função econômica-política-religiosaprocracional" da família para uma nova função, qual seja, "converter-se em espaço de realização da afetividade humana", sendo, portanto, substituída a rígida estrutura hierárquica pela "coordenação e comunhão de interesses de vida". (LÔBO, 2011, p. 22)

\begin{abstract}
A mudança mais recente e que mais influenciou o modus vivendi foi a sua passagem de uma instituição econômica e patriarcal para um núcleo afetivo, voltado para a promoção da personalidade e da dignidade de seus membros. A família passou a existir em função de seus componentes, e não o contrário. (TEIXEIRA, 2003, p. 4).
\end{abstract}

Apesar do Direito caminhar em velocidade distinta da transformação social, ele não está à sua margem, vez que há significativa preocupação quanto à regulamentação, se possível, de questões referentes ao direito das famílias.

\footnotetext{
1 Exame de DNA: “O estudo do perfil genético do DNA surgiu por volta de 1953, quando os cientistas James Watson e Francis Crick descobriram a estrutura de dupla hélice do ácido desoxirribonucleico. No entanto, as técnicas para a análise das informações genéticas de cada indivíduo somente começaram a surgir em 1980. O grande avanço científico realizou-se em 1985, quando Alec Jeffreys criou sondas moleculares radioativas com a propriedade de reconhecer regiões altamente sensíveis do DNA, sendo possível, então, identificar os padrões específicos de cada pessoa, chamado, pelo cientista, de impressão genética. Até então, as ações de investigação de paternidade eram instruí- das a partir de exames de sangue muito mais simples, que não possuíam o índice de certeza oferecido pelo exame de DNA, método científico capaz de identificar algumas informações genéticas herdadas pelo indivíduo, que, na verdade, são combinações de genes do pai e da mãe. Após o seu advento, a análise do DNA tornou-se o meio de prova mais utilizado nas ações de investigação de paternidade, transformando muitos onceitos do ordenamento jurídico, principalmente, aqueles inerentes ao reconhecimento do estado de filho". (BORTOLOTTO, 2005, p. 41-2).
} 
No entanto, pela investigação realizada, entende-se serem três os fatores que podem ser elencados como preponderantes em relação à ausência de normatização em determinados assuntos relacionados a esta seara do Direito:

Os dois primeiros são questões de jaez moral e religiosa, pois em que pese a Constituição prever a liberdade de consciência e de crença², estas influências estão perpetuadas no cotidiano social. Por outro lado, o terceiro fator a ser mencionado é a dificuldade em estabelecer conceitos e limites a situações que fogem à objetividade inerente à regulamentação jurídica, pois necessitam do subsídio de outras áreas do conhecimento como a Sociologia, a Filosofia e a Psicologia. Assim, é necessário buscar em outros contornos a designação para a terminologia afeto, a fim de obter fundamento para correlacioná-la cientificamente à área jurídica.

A palavra afeto possui inúmeras designações, podendo partir da linguagem natural para designar o mais nobre dos sentimentos ou até mesmo partindo da linguagem filosóficocientífica para designar todas as afeições, desde aquelas mais elevadas até mesmo as que refletem os sentimentos mais repudiados. (ROCHA, 2009) No entanto, como já afirmado alhures, para que haja a convergência para os reflexos na seara jurídica é necessário vislumbrar o afeto a partir do aspecto social e psicológico, abrangendo exclusivamente os sentimentos nobres, ou seja, atribuindo a este fato uma conotação eminentemente positiva.

A correlação entre o fenômeno social e o fenômeno normativo dá origem ao termo socioafetividade, considerando que "de um lado há o fato social e de outro o fato jurídico. A norma é o princípio jurídico da afetividade. As relações familiares e de parentesco são socioafetivas, porque congrega o fato social (sócio) e a incidência do princípio normativo (afetividade)". (LÔBO, 2011, p. 29)

Em que pese a ausência normativa quanto a conceituação acerca da afetividade na legislação brasileira, ela passou a ser considerada como um dos elementos fundamentais não somente para identificar como também para solidificar as relações parentais. Reconhecida inicialmente pela doutrina, a afetividade enquanto princípio norteador do direito das famílias passou a compor a identificação dos novos arranjos familiares construídos (neles inseridas as relações materno e paterno-filiais) e, consequentemente, a influenciar de forma significativa as decisões judiciais.

\footnotetext{
${ }^{2}$ CRFB/1988. "Art. 50 Todos são iguais perante a lei, sem distinção de qualquer natureza, garantindo-se aos brasileiros e aos estrangeiros residentes no País a inviolabilidade do direito à vida, à liberdade, à igualdade, à segurança e à propriedade, nos termos seguintes: [...] VI - é inviolável a liberdade de consciência e de crença, sendo assegurado o livre exercício dos cultos religiosos e garantida, na forma da lei, a proteção aos locais de culto e a suas liturgias; [...]".
} 
Vista sob esse prisma, a afetividade deixa de ser apenas “[...] fato psicológico ou anímico, porquanto pode ser presumida quando este faltar na realidade das relações; assim, a afetividade é dever imposto aos pais em relação aos filhos e destes em relação àqueles, ainda que haja desamor ou desafeição entre eles” (LOBO, 2011, p. 71).

Desse modo, a afetividade passa a ser materializada juridicamente pelo dever de cuidado, assistência, zelo e atenção dispensados no exercício do poder familiar, em se tratando da relação materno e paterno-filial, bem como por parte dos filhos em relação aos seus pais quando vulneráveis.

Neste caso, não se está a discutir o amparo material, objeto inclusive de tipificação ${ }^{3}$, mas sim o amparo emocional e psicológico, a partir do qual é possível reconhecer, na relação parental, pessoas que são detentoras de dignidade e direitos que precisam ser devidamente resguardados.

Em razão da relevância deste princípio implícito constitucionalmente e previsto expressamente em determinadas leis direcionadas à proteção das famílias, faz-se necessário tecer apontamentos a respeito da proteção legal deste elemento fundamental na identificação das relações parentais hodiernas.

\section{AS RELAÇÕES PARENTAIS E A AFETIVIDADE ENQUANTO FENÔMENO DE NATUREZA JURÍDICA}

Vistas as mutações das relações parentais no que tange à evolução histórica, importa, ainda, tratar da afetividade a partir da sua recepção pelo ordenamento jurídico brasileiro para, a posteriori, discutir o seu reverso (abandono afetivo).

Assim sendo, apesar da Constituição não estabelecer o afeto como elemento caracterizador da entidade familiar, o princípio da afetividade pode ser identificado de forma implícita como alicerce dos vínculos parentais, a partir da interpretação da base principiológica que fundamenta o sistema constitucional brasileiro.

[...] no Direito de Família é de substancial importância a efetividade dos princípios que difundem o respeito e a promoção da dignidade humana e da solidariedade, considerando que a família contemporânea é construída e valorizada pelo respeito à plena liberdade e felicidade de cada um de seus componentes, não podendo ser concebida qualquer restrição ou vacilo a este espaço constitucional da realização do homem em sua relação sociofamiliar. (MADALENO, 2013, p. 45)

\footnotetext{
${ }^{3}$ CP/1940. “Art. 244. Deixar, sem justa causa, de prover à subsistência do cônjuge, ou de filho menor de dezoito anos ou inapto para o trabalho, ou de ascendente inválido ou valetudinário, não lhes proporcionando os recursos necessários ou faltando ao pagamento da pensão alimentícia judicialmente fixada; deixar, sem justa causa, de socorrer descendente ou ascendente, gravemente enfermo: [...]”.
} 
Neste sentido, o macroprincípio da dignidade da pessoa ${ }^{4}$ remete à supervalorização desta e, em contrapartida, à diminuição da importância do patrimônio em comparação à entidade familiar identificada em tempos remotos. (TARTUCE, 2008) Aquele princípio representa "um valor fundamental de respeito à existência humana, segundo as suas possibilidades e expectativas, patrimoniais e afetivas, indispensáveis à sua realização pessoal e à busca da felicidade" (GAGLIANO, PAMPLONA FILHO, 2011, p. 74). Partindo deste contexto, é possível extrair que a dignidade da existência da pessoa atribui sentido jurídico à afetividade justamente a partir da sua caracterização como mola propulsora dos laços familiares e das relações interpessoais. (MADALENO, 2013)

Nesta mesma senda encontra-se a solidariedade que, enquanto princípio ${ }^{5}$, tem origem nos vínculos afetivos e dispõe de acentuado conteúdo ético, considerando que possui em "suas entranhas o próprio significado da expressão solidariedade, que compreende a fraternidade e a reciprocidade" (DIAS, 2011, p. 66). Constitucionalmente restam valorados os deveres de assistência, criação e educação dos filhos, extensivos aos filhos quanto aos pais sempre que necessário ${ }^{6}$. Esses não podem ser considerados em sua integralidade se também não estiver presente a proteção permeada pelo carinho e pelo amor: "a solidariedade é princípio e oxigênio de todas as relações familiares e afetivas, porque esses vínculos só podem se sustentar e se desenvolver em ambiente recíproco de compreensão e cooperação, ajudando-se mutuamente sempre que se fizer necessário" (MADALENO, 2013, p. 93).

Ampliando a "titularidade" desse dever, Dias (2011) afirma que a solidariedade pode ser traduzida como um socorro espiritual e de assistência material, tendo o texto constitucional atribuído-o primeiramente à família, depois à sociedade e, finalmente, ao Estado.

$\mathrm{O}$ princípio da convivência familiar ${ }^{7}$ assegura prioridade absoluta à criança, ao adolescente e ao idoso, numa relação edificada no afeto, uma vez que dentre outros fatores se

4 CRFB/1988. "Art. 1. A República Federativa do Brasil, formada pela união indissolúvel dos Estados e Municípios e do Distrito Federal, constitui-se em Estado Democrático de Direito e tem como fundamentos: [...] III - a dignidade da pessoa humana; [...]".

${ }^{5}$ CRFB/1988. “Art. $3^{\circ}$, I. Constituem objetivos fundamentais da República Federativa do Brasil: I - construir uma sociedade livre, justa e solidária; [...]".

${ }^{6}$ CRFB/1988. "Art. 229. Os pais têm o dever de assistir, criar e educar os filhos menores, e os filhos maiores têm o dever de ajudar e amparar os pais na velhice, carência ou enfermidade".

7 CRFB/1988. "Art. 227. É dever da família, da sociedade e do Estado assegurar à criança, ao adolescente e ao jovem, com absoluta prioridade, o direito à vida, à saúde, à alimentação, à educação, ao lazer, à profissionalização, à cultura, à dignidade, ao respeito, à liberdade e à convivência familiar e comunitária, além de colocá-los a salvo de toda forma de negligência, discriminação, exploração, violência, crueldade e opressão"; Lei 10.741/2003 (Estatuto do Idoso). “Art. $3^{\circ}$. É obrigação da família, da comunidade, da sociedade e do Poder Público assegurar ao idoso, com absoluta prioridade, a efetivação do direito à vida, à saúde, à alimentação, à educação, à cultura, ao esporte, ao lazer, ao trabalho, à cidadania, à liberdade, à dignidade, ao respeito e à convivência familiar e comunitária" 
busca a prevenção da prática de atos nocivos aos interesses destes vulneráveis, lembrando que "a convivência familiar é a relação afetiva diuturna e duradoura entretecida pelas pessoas que compõem o grupo familiar, em virtude de laços de parentesco ou não, no ambiente comum". (LÔBO, 2015, p. 121)

A afetividade, enquanto princípio implícito na base axiológica constitucional, também pode ser reconhecida a partir da interpretação de determinados dispositivos legais, como ocorre com o artigo 1.593 do Código $\mathrm{Civil}^{8}$, que atribui outras formas de vinculação paterno ou materno-filial além da origem consanguínea. Somado a isto, o Enunciado 108 da Jornada de Direito Civil - CJF/STJ ainda estabelece que “[...] no fato jurídico do nascimento, mencionado no art. 1.603, compreende-se, à luz do disposto no art. 1.593, a filiação consanguínea e também a socioafetiva".

Outras formas de demonstração da importância do afeto nas relações familiares podem ser encontradas na legislação esparsa, como por exemplo, na previsão da igualdade da filiação (CC, artigo 1.596); na inseminação heteróloga (CC, 1.597, inciso V); na guarda unilateral e compartilhada (CC artigo 1.584); na garantia social e estatal da inviolabilidade da integridade psíquica e moral do idoso (Estatuto do Idoso, artigo $10, \S 2^{\circ}$ ); na previsão do acolhimento da pessoa idosa em família substituta para propiciar condições de respeito a sua dignidade da pessoa idosa e para assegurar o exercício dos demais direitos e garantias individuais (Estatuto do Idoso, artigo 37); na previsão de proteção dos vulneráveis contra o abandono moral e material por parte de familiares (Estatuto do Idoso, artigo 50, XVI); na compreensão da família extensa ou ampliada e na manutenção de vínculos de afinidade e afetividade com a criança ou adolescente (ECA art. 25, parágrafo único); na preservação dos vínculos em relação à família substituta (ECA art. 28, $\S 3^{\circ}$ ); na necessidade de comprovação da existência de vínculos de afinidade e afetividade como pressupostos da adoção e guarda (ECA art. $42, \S 4^{\circ}$ e art. $50, \S 13^{\circ}$, incisos II e III).

Com esses ilustrativos exemplos se busca demonstrar a importância da afetividade como pilar, pressuposto e amálgama das relações parentais na atualidade, não somente por se admitir que assim o seja na realidade das famílias na contemporaneidade, mas também por ter sido devidamente recepcionada pelo ordenamento jurídico brasileiro, seja a partir da interpretação do arcabouço axiológico, seja por expressa previsão normativa.

Diante deste cenário é possível inferir que a ausência deste elemento fundamental nos arranjos familiais modernos, precisamente nos vínculos materno e paterno-filial, bem como na

\footnotetext{
${ }^{8}$ CC/2002. “Art. 1.593. O parentesco é natural ou civil, conforme resulte de consanguinidade ou outra origem".
} 
relação inversa, pode ocasionar significativas consequências de ordem moral e jurídica ensejando, inclusive, a identificação da responsabilidade civil por parte daqueles que deixaram de propiciar assistência afetiva aos filhos ou aos seus pais.

Precisamente aí se percebe a força estatal se imiscuindo nas relações privadas dos indivíduos e então o abandono afetivo passa a merecer uma análise mais aprofundada sob essa perspectiva, procurando-se estabelecer objetivamente os critérios motivadores das suas consequências jurídicas, e os limites dessa intervenção.

\section{O RECONHECIMENTO DO ABANDONO AFETIVO COMO CONSEQUENCIA DO DESCUMPRIMENTO DE DEVERES JURÍDICOS}

A partir do momento em que a afetividade passou a ser considerada como o alicerce dos laços familiares, a sua ausência pode gerar um abalo significativo nestas relações, gerando consequências que vão muito além de prejuízos de ordem material, podendo violar a integridade psíquica e moral do indivíduo.

O papel da família é extremamente importante em qualquer estágio da vida, mas apresenta-se de forma ainda mais relevante nas fases de vulnerabilidade da pessoa: infância, adolescência e melhor idade, nas quais mais necessita de cuidado, zelo e atenção.

Nesse ponto, entretanto, é necessário pontuar que o abandono afetivo não está relacionado a ausência de afeto, enquanto sentimento nobre, pois este deve ser algo voluntário e acima de tudo espontâneo. Isso porque não há como exigir que alguém tenha o seu estado de espírito moldado a este ou aquele comportamento. A afetividade aqui relacionada se refere à responsabilidade parental, insculpida no texto constitucional, a partir dos artigos $227^{9}$ e $229^{10}$ : ela efetiva os princípios constitucionais aplicáveis à relação parental analisados acima, viabilizando a assistência, a criação e a educação dos filhos, bem como o amparo dos filhos em relação aos pais idosos e vulneráveis.

Efetivamente, amar não é dever ou direito. Amar é sentimento intangível pelo Direito.
A falta de amor, como sentimento, portanto, não pode gerar indenização. Mas o dever
do pai e da mãe de ter o filho em sua companhia e educá-lo, de natureza objetiva, está
previsto no art. 1.634, I e II do Código Civil. O Estatuto da Criança e do Adolescente
prevê também deveres para os pais, como o dever de assegurar o desenvolvimento
físico, mental, moral, espiritual e social do filho menor, em condições de dignidade
$\left(\right.$ ECA, arts. $3^{\circ}, 4^{\circ}$ e $5^{\circ}$ ). Esses, sim, são deveres de natureza jurídica, cujo

${ }^{9}$ CRFB/1988. “Art. 227. É dever da família, da sociedade e do Estado assegurar à criança, ao adolescente e ao jovem, com absoluta prioridade, o direito à vida, à saúde, à alimentação, à educação, ao lazer, à profissionalização, à cultura, à dignidade, ao respeito, à liberdade e à convivência familiar e comunitária, além de colocá-los a salvo de toda forma de negligência, discriminação, exploração, violência, crueldade e opressão".

${ }^{10}$ CRFB/1988. "Art. 229. Os pais têm o dever de assistir, criar e educar os filhos menores, e os filhos maiores têm o dever de ajudar e amparar os pais na velhice, carência ou enfermidade". 
descumprimento, ao gerar danos, pode acarretar a condenação do inadimplente em pagamento de indenização. (TAVARES DA SILVA, 2012)

E complementando o raciocínio acima esposado, pode-se afirmar que o abandono afetivo é, muitas vezes, muito mais que o

[...] inadimplemento de obrigações decorrentes dos laços familiares, ele consiste numa forma de violência psicológica ou negligência, sob a qual a criança, adolescente ou idoso é exposto, já que é privado da convivência familiar, como também lhe é negado o suporte psíquico, afetivo e moral que necessita em razão de sua vulnerabilidade. (CONSALTER, 2015, p. 35)

Assim entendido, é realmente impossível fechar os olhos para algo que faz parte da realidade das famílias contemporâneas, principalmente pelo fato de que tanto crianças e adolescentes, bem como os idosos, são merecedores de total prioridade de tratamento, uma vez que devem sempre estar no epicentro da órbita familiar.

Abra-se espaço para lembrar que a representação da família contemporânea não mais contempla a figura piramidal e hierárquica, em que os filhos ocupavam a escala mais baixa. Ela segue no sentido de coloca-los num lugar central representado por uma circunferência que é desenhada pelas recíprocas relações com seus pais e/ou mães. (POCAR; RONFANI apud LÔBO, 2015), sendo que esta estrutura metafórica também pode ser extensiva, evidentemente, ao idoso.

Neste sentido surgem na jurisprudência várias demandas ${ }^{11}$ que retratam casos de abandono afetivo dos pais em relação aos seus filhos. No entanto, no que tange aos idosos, até a conclusão desta pesquisa não houve a identificação de ações procedentes tendo como objeto a ocorrência do abandono inverso, ou seja, da carência da devida proteção dos filhos em relação aos seus pais, pela objetiva ausência de cuidados, de convivência familiar, de assistência moral e psíquica:

\begin{abstract}
Desenvolve-se no âmbito do Direito de Família estudos relativos ao "cuidado como valor jurídico". O cuidado desponta com força nos estatutos tutelares das pessoas vulneráveis, como a criança e o idoso, que regulamentaram os comandos constitucionais sobre a matéria. O cuidado, sob o ponto de vista do direito, recebe a força subjacente do princípio da solidariedade, como expressão particularizada desta. (LỔBO, 2015, p. 121)
\end{abstract}

${ }^{11}$ Ad exemplum: BRASIL. STJ. REsp. no. 757.411-MG (2005/0085464-3). Rel. Min. Fernando Gonçalves. J. em 29 de novembro de 2005 e publicado no DJ. em 27 de março de 2006; BRASIL. STF. REx. 567.164-ED/MG. Rel. Min. Ellen Gracie. J. em 18 de agosto de 2009 e publicado no DJE em 11 de setembro de 2009; BRASIL. STJ. REsp. no. 1.159.242-SP (2009/0193701-9). Rel. Min. Nancy Andrighi. J. em 24 de abril de 2012 e publicado no DJE em 10 de maio de 2012; e, ainda, a decisão monocrática: RIO GRANDE DO SUL. TJRS. Comarca de Capão da Canoa. $2^{\text {a }}$ Vara. Processo no 141/1030012032-0. Juiz de Direito Mario Romano Maggioni. J. em 15.09.2003, por ser pioneira (CONSALTER, 2015, p. 37, nota 86). 
Dessa maneira, tendo o dever de cuidado reconhecida natureza objetiva, bem como os deletérios efeitos de sua ausência sejam reprovados pelo sistema jurídico uma vez que "[...] os expertos em psicologia têm afirmado que o filho abandonado por seu pai sofre trauma e ansiedade, com nefasta repercussão em suas futuras relações, ressentidas de autoconfiança" (MEDINA apud MADALENO, 2013, p. 383), surge, a partir deste contexto, por parte do Estado, o interesse em regulamentar expressamente a questão do abandono afetivo, a fim de delimitar o seu conceito e, consequentemente, atribuir efeitos jurídicos quando da sua ocorrência.

Nesta perspectiva, é possível visualizar no cenário a seguir descrito, especialmente no que tange à atuação do Estado, a busca da objetivação da temática relacionada ao abandono afetivo.

\subsection{ESBOÇANDO A FIGURA DO ABANDONO AFETIVO: PROJETOS DE LEI EM TRAMITAÇÃ̃O}

No ano de 2007, o Projeto de Lei do Senado $n^{\circ}$ 700/2007 (BRASIL, 2007), de autoria do Senador Marcelo Crivella, propôs a modificação do Estatuto da Criança e do Adolescente (doravante apenas ECA) para caracterizar o abandono moral como ilícito penal e civil, inclusive prevendo a possibilidade de reparação por dano moral gerado a partir do abandono.

A proposta constava da inserção dos $\S \S 2^{\circ}$. e $3^{\circ}$. no artigo $4^{\circ}$. da Lei 8.069/1990 (ECA) para definir a compreensão do dever de assistência moral que passaria a constar de forma expressa no texto legal e, ainda a consequente reparação de danos em virtude da prática de conduta ilícita, bem como a suspensão do "pátrio poder" (expressão ainda utilizada pelo texto legal, ao invés da correta expressão poder familiar) pelo descumprimento do dever de assistência moral ${ }^{12}$.

\footnotetext{
12 PLS no. 700/2007. “Art. $1^{\circ}$. O art. $4^{\circ}$ da Lei $n^{\circ} .8 .069$, de 13 de julho de 1990, passa a vigorar acrescido dos seguintes $\S \S 2^{\circ}$ e $3^{\circ}$, renumerado o atual parágrafo único como $\S 1^{\circ}$ : ' $\left[\right.$...] $\$ \mathbf{2}^{\mathbf{o}}$. Compete aos pais, além de zelar pelos direitos de que trata o art. $3^{\circ}$ desta Lei, prestar aos filhos assistência moral, seja por convívio, seja por visitação periódica, que permitam o acompanhamento da formação psicológica, moral e social da pessoa em desenvolvimento. $\$ \mathbf{3}^{\mathbf{o}}$. Para efeitos desta Lei, compreende-se por assistência moral devida aos filhos menores de dezoito anos: I - a orientação quanto às principais escolhas e oportunidades profissionais, educacionais e culturais; II - a solidariedade e apoio nos momentos de intenso sofrimento ou dificuldade; III - a presença física espontaneamente solicitada pela criança ou adolescente e possível de ser atendida."”. "Art. $2^{\circ}$. Os arts. 5, 22, 24, 56, 58, 129 e 130 da Lei $n^{\circ} .8 .069$, de 13 de julho de 1990, passam a vigorar com as seguintes alterações: '[...] Parágrafo único. Considera-se conduta ilícita, sujeita a reparação de danos, sem prejuízo de outras sanções cabíveis, a ação ou a omissão que ofenda direito fundamental de criança ou adolescente previsto nesta Lei, incluindo os casos de abandono moral"; "Art. 22. Aos pais incumbe o dever de sustento, guarda, convivência, assistência material e moral e educação dos filhos menores, cabendo-lhes ainda, no interesse destes, a obrigação de cumprir e fazer cumprir as determinações judiciais". "Art. 24. A perda e a suspensão do pátrio poder serão decretadas judicialmente, em procedimento contraditório, nos casos previstos na legislação civil, bem como na hipótese de descumprimento injustificado dos deveres e obrigações a que aludem o art. 22.”.
} 
Como já informado, a proposta inicial do referido projeto de lei também foi alterar o ECA para tipificar a conduta omissiva como ilícito penal com pena de detenção de um a seis meses. ${ }^{13}$ Em sua justificativa, o legislador fundamentou a prevenção e a solução de casos intoleráveis de negligência para com os filhos, os quais vão além dos deveres materiais de subsistência:

Fique claro que a pensão alimentícia não esgota os deveres dos pais em relação a seus filhos. Seria uma leitura muito pobre da Constituição e do ECA. A relação entre pais e filhos não pode ser reduzida a uma relação monetária, de cifras. Os cuidados devidos às crianças e adolescentes compreendem atenção, presença e orientação. (BRASIL, 2007, p. 7)

No entanto, em setembro de 2015 o mencionado PLS foi aprovado pela Comissão de Direitos Humanos com a proposta somente da caracterização do abandono afetivo como ilícito civil passível de reparação, afastando a possibilidade da utilização do direito penal como forma de punição. Além disso, alterou a denominação assistência moral para assistência afetiva, mantendo a conceituação inicialmente prevista ${ }^{14}$.

Por outro lado, na Câmara dos Deputados foi proposto pelo Deputado Carlos Bezerra o Projeto de Lei 4294/2008 (BRASIL, 2008) para alteração do Código Civil (artigo 1.632) e do Estatuto do Idoso (artigo $3^{\circ}$ ) prevendo a reparação por dano moral quando da ocorrência de abandono afetivo, porém o conceito de abandono afetivo não foi previsto expressamente.

Em 19 de setembro de 2013 o Deputado Federal Marcelo Almeida propôs substitutivo (BRASIL, 2013a) ao Projeto de Lei da Câmara 4294/2008, sob o fundamento de que se trata de texto muito abrangente e com margens para distorções na compreensão da questão afetiva. Somado a isso, considera o abandono afetivo um tema delicado e complexo e que, portanto, merece maior atenção, e também porque a partir da sua definição haverá implicações jurídicas significativas. Assim, o substitutivo não definiu abandono afetivo, mas considerou expressamente o dano moral, passível de indenização a partir do descumprimento dos deveres dos pais, bem como o descumprimento dos deveres dos descendentes em relação aos ascendentes idosos.

Também se encontra em trâmite junto ao Senado Federal, o Projeto de Lei 470/2013 (BRASIL, 2013b), intitulado Estatuto das Famílias, de autoria da Deputada Lídice da Mata, que tem a proposta de inserção do abandono afetivo como ilícito civil passível de reparação, definindo a assistência afetiva direcionada à criança e ao adolescente. No que se refere ao

\footnotetext{
${ }^{13}$ PLS no. 700/2007. “Art. $3^{\circ}$ A Lei n’. 8.069, de 13 de julho de 1990, passa a vigorar acrescida do seguinte art.
} 
232-A: “Art. 232-A. Deixar, sem justa causa, de prestar assistência moral ao filho menor de dezoito anos, nos termos dos $\S \S 2^{\circ}$ e $3^{\circ}$ do art. $4^{\circ}$ desta Lei, prejudicando-lhe o desenvolvimento psicológico e social. Penadetenção, de um a seis meses."

${ }^{14}$ PLS no. 700/2007. " $§ 3^{\circ}$ Para efeitos desta Lei, compreende-se por assistência afetiva: I - orientação quanto às principais escolhas e oportunidades profissionais, educacionais e culturais; II - solidariedade e apoio nos momentos de intenso sofrimento ou dificuldade; III - presença física espontaneamente solicitada pela criança ou adolescente e possível de ser atendida."tratamento dispensado ao abandono afetivo, o mencionado projeto apresenta a seguinte justificativa:

\begin{abstract}
Abandono afetivo. A absoluta prioridade ao convívio familiar assegurada a crianças e adolescentes dispõe de respaldo constitucional, consubstanciada no princípio da paternidade responsável ( $\mathrm{CF}$, art. 227). Ainda que o amor não tenha preço, é indispensável assegurar o direito a exigir alguma espécie de reparação quando ocorre abandono afetivo. Cabe ser penalizada a negligência parental, cuja indenização pode ter natureza patrimonial ou extrapatrimonial. Para o Direito, o afeto não se traduz apenas como um sentimento, mas principalmente como dever de cuidado, atenção, educação, entre outros. (BRASIL, 2013b).
\end{abstract}

Em setembro de 2015 o referido projeto foi submetido à Comissão Direitos Humanos e Legislação Participativa, oportunidade em que foi aprovado o requerimento de iniciativa do Senador Magno Malta para submeter o Projeto à realização de audiências públicas dada a complexidade da matéria, o que justificaria a necessidade de se discuti-lo amplamente com toda a sociedade civil, juristas e entidades. (BRASIL, 2015)

Este cenário legislativo demonstra a preocupação do Estado em identificar objetivamente o abandono afetivo e atribuir consequências jurídicas quando da sua ocorrência.

No entanto, é necessário tomar cuidado quanto à delimitação desta matéria. Isso porque se deve evitar que haja a ampliação das suas consequências para áreas mais repressivas do Direito - e que devem ser utilizadas apenas de forma subsidiária (como é o caso do Direito Penal) -, bem como para rechaçar o engessamento do sistema legal a partir da pontual delimitação da conduta caracterizadora do abandono afetivo, dadas as circunstâncias casuísticas apresentadas em cada caso concreto. Por estes e por outros motivos faz-se necessária a abordagem em relação às consequências da intervenção estatal na delimitação desta importante temática.

\title{
4.2 DEFININDO LIMITES À ATUAÇÃO DO ESTADO NA ESFERA PRIVADA DAS PESSOAS
}

O primeiro aspecto a ser considerado quanto a intervenção estatal no campo privado das pessoas é o pertinente ao afastamento legal da incidência penal como forma de coerção no que se refere ao abandono afetivo. Isso porque atualmente a sociedade tem clamado por maior proteção, inclusive recorrendo ao Direito Penal como tentativa de coibição de comportamentos 
em diversas searas da vida cotidiana, mas nem tudo deve ser tipificado ou ser motivo de penalização, especialmente na esfera em comento.

A partir da denominada expansão do Direito Penal (SILVA SÁNCHEZ, 2013), surge a tipificação de comportamentos não necessariamente lesivos, mas que apontam para um possível risco de lesão:

\begin{abstract}
Diante do repentino descontrole gerado, dentre outros fatores, pelo aparecimento de outros riscos e agravamento dos já existentes, o Estado passou a utilizar-se do maior instrumento de repressão que possui - o direito penal - com o objetivo de controlar os riscos provenientes da ação humana, através da coibição de comportamentos não necessariamente lesivos no momento em que são praticados, mas que apontam para um risco de eminente lesão. (SEBASTIÃO FILHO, 2012, p. 22). (destaque das autoras).
\end{abstract}

Assim, a priori, tipificar condutas e impor punições parece ser a melhor forma de prevenir delitos e lidar com os riscos na sociedade contemporânea. No entanto, esta hipótese não pode ser levada em consideração nestes termos, ou seja, o Direito Penal não seria a melhor forma de prevenir, porém a última alternativa a ser utilizada para proteção de outras áreas do ordenamento jurídico.

No entanto, a utilização do Direito Penal para a tipificação da conduta relacionada ao abandono afetivo, além de representar uma de afronta à liberdade do indivíduo, também caracteriza afronta aos princípios da intervenção mínima e da subsidiariedade:

En la actualidad el principio de intervención mínima es tenido como una garantía
frente al poder punitivo del Estado y configura, por tanto, el fundamento de los
ordenamientos jurídicos-penales de los Estados de Derecho. Supone que El Derecho
penal solo debe intervenir en los casos de ataques muy graves a los bienes jurídicos
más importantes. (MILANESE 2003, p. 303-304)

Dessa forma, o afastamento da incidência penal no que se refere ao abandono afetivo demonstra a coerência e a preocupação do legislador em utilizar o Direito Penal como ultima ratio, a fim de evitar que as garantias individuais e as próprias funções do direito penal sejam postos em risco, gerando resultados que afrontem a base axiológica do Estado Democrático de Direito.

Por outro prisma - mas ainda na senda de desenhar fronteiras ao Estado no que tange a se imiscuir na área privatística do indivíduo -, ainda há que se destacar que não há omissão do legislador quanto à importância da temática relacionada ao abandono afetivo, tanto que, como visto alhures, há a previsão dos deveres provenientes da relação parental (tanto dos pais em relação aos filhos como vice-versa) em vários diplomas legais e a reparação civil pelo seu inadimplemento já vem sendo aquiescida por diversos tribunais pátrios e, evidentemente, pela melhor doutrina: 
[...] a possibilidade de demandar-se em razão de abandono afetivo não ser verifica de forma desarrazoada, irresponsável, ou desapegada da realidade. O molde jurídico para o restabelecimento da situação foi pensado pelo Direito há muito tempo. O que se assiste, atualmente, é uma adaptação do figurino clássico da responsabilidade civil nos casos que decorrem de situações de Direito de Família e entre membros de uma mesma família sem que isso implique subversão do sistema. Também a obrigação jurídica violada existe há muito tempo. O que ocorre é o necessário repensar desses direitos e deveres, que passam a ser permeados com o afeto, agraciados com a despatrimonialização das relações, pautados pela função de esteio e de alicerce para a dignidade humana, deixando de lado o autoritarismo, a perversão e o direito de disposição mais ou menos limitado a respeito do futuro dos filhos. (HIRONAKA, 2005, p. 468)

E parece que seja exatamente aí que o Estado deve estagnar sua intromissão, pois qualquer definição pontual ou muito hermética do que seja abandono afetivo poderia mais excluir do que incluir possibilidades em que a violação aos deveres parentais possa ser evidenciada. Isso implica dizer que a previsão legal do dever jurídico ligado ao abandono afetivo seja positiva, mas a definição legal do instituto, não:

\begin{abstract}
O direito opera selecionando os fatos da vida que devem receber a incidência da norma jurídica. Por isso, sem qualquer contradição, podemos referir a dever jurídico de afetividade oponível a pais e filhos e aos parentes entre si, em caráter permanente, independentemente dos sentimentos que nutram entre si, e aos cônjuges e companheiros enquanto perdurar a convivência. (LÔBO, 2015, p. 119)
\end{abstract}

E esse fenômeno pode ocorrer com outros conceitos correlatos ao abandono afetivo, tais como a assistência afetiva, prevista no PLS no. 700/2007 ${ }^{15}$, por exemplo. Esse é o típico caso de conceituação que exclui outros eventos que poderiam ser considerados como enquadrados numa acepção ampla (cláusulas e conceitos abertos), que sempre será mais inclusiva que o método fechado de legislar.

Só para tornar mais nítido o exemplo do dispositivo transcrito em nota, poder-se-ia arguir: como conceber "principais escolhas"? O que significa "intenso sofrimento ou dificuldade"? E mais: o que caracteriza o abandono afetivo seria a presença física dos pais? Bem, tentar definir legalmente um instituto tão complexo só gera incertezas, insegurança e exclusão, fato que já fora percebido pelo legislador do Código Civil, que abandonou essa metodologia, adotou aquela que prefere a dos conceitos abertos e confere ao julgador do caso em concreto a possibilidade de exegese pautada nas individualidades da demanda. Isso porque embora as expressões acima comentadas sejam conceitos abertos, o que se defende é que o termo "abandono afetivo" é que deveria ser mantido em aberto, e não os elementos que tentam delineá-lo.Isso implica dizer que nesse ponto o Estado não labora bem e nem contribui para sanar um problema privado, mas com consequências sociais. Para isso, sugere-se ou a omissão legislativa quanto às conceituações, ou ainda, caso se entenda necessária, que seja a mesma feita empregando-se o sistema de cláusulas gerais. 
Ótima iniciativa nesse sentido pode ser encontrada no PLC no. 4294/2008 ${ }^{16}$, que prevê, pelo seu substitutivo, a inserção dos parágrafos únicos no Código Civil e no Estatuto do Idoso, em que se averigua a preocupação com a relação parental como um todo (criança, adolescente e idoso) e não de forma conclusiva e definitiva. Nesse caso não houve delimitação do abandono afetivo, somente a previsão de que havendo a ocorrência de dano moral ou material será passível de indenização, remetendo à análise às situações fáticas, podendo-se aferir o regramento sobre o instituto, mas não o engessamento do sistema jurídico-legal e nem a insurgência de forma violenta pelo ente estatal na seara privada das pessoas.

Mesma sorte não teve o PLS no. 470/2013 (Estatuto das Famílias) que embora tenha feito a previsão de consequências jurídicas mediante a constatação de abandono afetivo ${ }^{17}$, faz somente quanto as crianças e adolescentes, esquecendo-se do idoso que, igualmente, pode padecer do mesmo mal. Essa exclusão legal prejudica o delineamento do abandono afetivo e é falha a ser sanada antes que haja a votação do referido PLS, até porque a "relação paterno-filial não é marcada pela transitoriedade" (HIRONAKA, 2005, p. 460). Isso sem falar nas críticas já tecidas quanto ao PLS no. 700/2007 quanto à abertura do conceito, que restam mantidas quanto a este diploma legal também.

Um terceiro aspecto a ser pontuado seria no sentido de contribuir para que não ocorra a intervenção exagerada da pessoa jurídica no âmbito privatístico familiar: ao invés de penalizar (ou então, somente de regrar, em última hipótese), o papel maior do Estado na esfera do Direito das Famílias talvez seja o de estabelecer políticas gerais que mitiguem o abandono afetivo.

\footnotetext{
${ }^{15}$ PLS no. 700/2007. “[...] $\S 3^{\circ}$ para efeitos desta lei, compreende-se por assistência afetiva: I - orientação quanto às principais escolhas e oportunidades profissionais, educacionais e culturais; II - solidariedade e apoio nos momentos de intenso sofrimento ou dificuldade; III - presença física espontaneamente solicitada pela criança ou adolescente e possível de ser atendida".

${ }^{16}$ PLC no. 4294/2008. "Art. 1632. [...] Parágrafo único: o descumprimento dos deveres dos pais que cause dano moral ou material ao filho sujeita o infrator ao pagamento de indenização. [...] o parágrafo único do art. $3^{\circ}$ da lei $\mathrm{n}^{\circ} 10.741$, de $1^{\mathrm{a}}$ de outubro de 2003 - Estatuto do Idoso - passa a vigorar como parágrafo $1^{\circ}$, devendo ser acrescido o seguinte parágrafo $2^{\circ}$ ao artigo: 'art. $3^{\circ}$. $\S 1^{\circ}$. $\S 2^{\circ}$ o descumprimento dos deveres dos descendentes que cause dano moral ou material aos ascendentes sujeita o infrator ao pagamento de indenização"”.

17 PLS no. 470/2013. "Art. 108. Considera-se conduta ilícita o abandono afetivo, assim entendido a ação ou a omissão que ofenda direito fundamental da criança ou adolescente."; "Art. 109. Compete aos pais, além de zelar pelos direitos estabelecidos em lei especial de proteção à criança e ao adolescente, prestar-lhes assistência afetiva, que permita o acompanhamento da formação da pessoa em desenvolvimento. Parágrafo único. Compreende-se por assistência afetiva: I - orientação quanto às principais escolhas e oportunidades profissionais, educacionais e culturais; II - solidariedade e apoio nos momentos de necessidade ou dificuldade; III - cuidado, responsabilização e envolvimento com o filho".
} 
Dessa maneira, a implementação de ferramentas públicas destinadas ao incentivo de atividades relacionadas à assistência social, à educação jurídica mais voltada à conciliação e menos ao litígio e à ética de modo geral, sempre visando a conferir a prevenção direcionada aos vulneráveis, vítimas - ou pretensas vítimas - de abandono afetivo, sejam uma resultante muito mais positiva que a postura estatal repressiva e/ou interventiva. Isso porque, a

[...] força determinante da afetividade, como elemento nuclear de efetiva estabilidade das relações familiares de qualquer natureza, nos dias atuais, torna relativa e, às vezes, desnecessária a intervenção do legislador. (LÔBO, 2015, p. 121)

Estes, entre outros inúmeros pontos podem ser levantados sobre o tema. Neste momento, o avanço da pesquisa realizada chegou a estas primeiras constatações, destacando-se que se trata de assunto de extrema complexidade e que exigirá dos cientistas jurídicos - e, em consequência, dos Poderes Legislativo e Judiciário - muito empenho e sensibilidade em sua análise.

\section{CONSIDERAÇÕES FINAIS}

A análise acerca da problemática que gira em torno da afetividade - enquanto substrato jurídico essencial no desenho da relação parental frente ao descumprimento dever objetivo jurídico de assistência mútua, que gera a responsabilidade pelo abandono afetivo - e a intervenção estatal visando mitigar essa prática ou as suas deletérias consequências, permite que se trace alguns pontos conclusivos:

Primeiro, que já não se pode conceber arranjo familiar sem o amálgama do afeto como substrato indispensável, donde se coliga a ideia de que o dever de assistência mútua seja um dever de caráter jurídico (além de moral, cristão e ético).

Segundo, em sendo o amparo emocional, afetivo e psíquico dos vulneráveis um dos elementos que compõem o cabedal de deveres dos pais para com os filhos e vice-versa, a sua carência gerará, em consequência, reflexos de ordem jurídica que devem ser previstos e regrados pelo Estado (primeiramente pelo legislador, mas na sua falta, pela exegese dos magistrados).

Terceiro, a previsão legislativa deve ser cuidadosa, a fim de que não se cometa o pecado do excesso, constatando-se a interferência estatal em esfera que não lhe cabe, como é o ramo do afeto puro (não enquanto instituto de natureza jurídica), do amor e consideração que deve ser uma constante nas relações familiais, mas que no plano ôntico nem sempre ocorre.Quarto, é preciso que se estabeleça limites e fronteiras a essa atuação estatal, de modo 
que se respeite, acima de tudo, o território autônomo da vontade e da liberdade do indivíduo no que diz respeito à contração e manutenção de liames de ordem emocional.

Quinto, e por outro prisma: não se pode deixar apenas ao alvitre das partes a manutenção das relações paterno-filiais. Cabe, sim, ao Estado, a definição de parâmetros e consequências jurídicas para o descumprimento de deveres de ordem objetiva, deixando-se os reflexos de ordem moral e emocional para o campo da Psicologia.

Sexto e derradeiro (ao menos por enquanto): é preciso que o Estado assuma o papel não de interventor nas relações familiares, mas sim de condutor das mesmas, donde se louva muito mais as práticas de prevenção que de punição, mais a mediação que a condenação. Por exemplo, isso pode ser materializado por meio das políticas públicas gerais que não somente informem acerca dos prejudiciais efeitos da prática do abandono afetivo, mas que criem uma cultura de paz e cuidados com os vulneráveis. Além disso, também podem ser previstas políticas públicas mais específicas, que busquem a mediação e conciliação entre ex-parceiros, (de modo que esse não seja um elemento que torne a convivência pós-ruptura matrimonial mais difícil), ou entre ascendentes e descendentes e vice-versa, evitando-se a prática do abandono afetivo de maneira direta. Veja-se que estes são apenas alguns exemplos do que pode ser feito.

Assim sendo, parece que talvez caiba com mais justeza essa tarefa estatal ao Poder Executivo - que pode estabelecer e implementar políticas públicas de educação, de mediação, de prevenção contra o abandono afetivo - que ao Poder Judiciário, a quem cabe condenar à reparação civil ou penalizar o que abandona um ente familiar em estado de vulnerabilidade.

\section{REFERÊECIAS}

BARROS, Sérgio Resende. A ideologia do afeto. Revista Brasileira de Direito de Família, Porto Alegre: Síntese, v. 4, n. 14, p. 5-10, jul./set. 2002.

BORTOLOTTO, Cristiane de Souza Rodrigues. O Exame de DNA e sua Influência nas Ações de Investigação de Paternidade. Direito \& Justiça, Porto Alegre: EDIPUCRS, ano XXVII , v. 31, n. 2, p. 41-89, 2005.

BRASIL. Constituição da República Federativa do Brasil de 1988, promulgada em 05 de outubro de 1988. D.O.U. de 05.10.1988. Planalto. Sítio oficial. Disponível em: http://www.planalto.gov.br/ccivil_03/constituicao/constituicao.htm. Acesso em: 28 mar. 2016.

BRASIL. Decreto-Lei no. 2.848, de 7 de dezembro de 1940. Código Penal. Publicado no DOU de 31.12.1940 e retificado em 3.1.1941. Disponível em: http://www.planalto.gov.br/ccivil_03/decreto-lei/del2848.htm. Acesso em: 04 abr. 2016. 
BRASIL. Estatuto da Criança e do Adolescente. Lei n. 8.069, de 13 de julho de 1990. Disponível em: <http://www.planalto.gov.br/ccivil_03/leis/18069.htm>. Acesso em: 04 abr. 2016.

BRASIL. Lei n. 10.246 de 10 de janeiro de 2002. Institui o Código Civil. D. O. U de 11.01.2002, Brasília, DF. Disponível em:

http://www.planalto.gov.br/ccivil_03/leis/2002/110406.htm. Acesso em: 04 abr. 2016.

BRASIL. Lei n. 10.741 de 1 de outubro de 2003. Dispões sobre o estatuto do idoso e dá outras providências. D. O. U de 03.10.2003, Brasília, DF. Disponível em: http://www.planalto.gov.br/ccivil_03/leis/2003/L10.741.htm. Acesso em: 04 abr. 2016.

BRASIL. Projeto de Lei no Senado no. 700/2007. Modifica a lei 8069 de 13 de julho de 1990, para caracterizar o abandono moral como ilícito civil e penal e dá outras providências. Senado Federal. Brasília, 06 dez. 2007. Disponível em:< http://www.senado.gov.br/atividade/materia/getPDF.asp?t=51685\&tp=1>. Acesso em: 30 mar. 2016.

BRASIL. Projeto de Lei na Câmara no. 4294/2008. Acrescenta parágrafo ao artigo 1. 632 da lei $\mathrm{n}^{\circ} 10.406$, de 10 de janeiro de 2002 - Código Civil e ao art. $3^{\circ}$ da lei $\mathrm{n}^{\circ} 10.741$, de $1^{\text {a }}$ de outubro de 2003 - Estatuto do Idoso -, de modo a estabelecer a indenização por dano moral em razão do abandono afetivo. Câmara dos Deputados. Brasília, 12 nov. 2008. Disponível em:

http://www.camara.gov.br/proposicoesWeb/prop_mostrarintegra;jsessionid=B51D360DD306 902EC17E462A7FA21090.proposicoesWeb2? codteor=613432\&filename=PL+4294/2008.

Acesso em: 03. abr. 2016.

BRASIL. Substitutivo ao PLC 4294/2008. Câmara dos Deputados. Brasília, 19 set. 2013a. Disponível em: http://www.camara.gov.br/proposicoesWeb/prop_mostrarintegra;jsessionid=B51D360DD306 902EC17E462A7FA21090.proposicoesWeb2?codteor $=1137704 \&$ filename=TramitacaoPL+4294/2008. Acesso em: 4 abr. 2016.

BRASIL. PLS no. 470/2013b. Dispõe sobre o Estatuto das Famílias e dá outras providências. Senado Federal. Brasília, 13 nov. 2013. Disponível em: http://www.senado.gov.br/atividade/Materia/getPDF.asp?t=140057\&tp=1. Acesso em: 03 abr. 2016.

BRASIL. Requerimento no. 73/2015-CDH. Senado Federal. Brasília, 01 jul. 2015. Disponível em: http://legis.senado.leg.br/mateweb/arquivos/mate-pdf/184933.pdf. Acesso em: 04 abr. 2016.

CONSALTER, Zilda Mara. O desamor e seus consectários jurídicos no âmbito do direito das famílias. In: PEREIRA, Dirce do Nascimento; CONSALTER, Zilda Mara (Orgs.). Questões controversas do direito das famílias na contemporaneidade. Belo Horizonte: Arraes, 2015. p. 24-46.

COULANGES, Numa Denis Fustel de. A cidade antiga. 4. ed. São Paulo: Martins Fontes, 1998.

DIAS, Maria Berenice. Manual de direito das famílias. 8. ed. rev.e atual. São Paulo: Revista dos Tribunais, 2011.

ENGELS, Friedrich. A origem da família, da propriedade privada e do Estado. 12. ed. Rio de Janeiro: Bertrand Brasil, 1991. 
GAGLIANO, Pablo Stolze; PAMPLONA FILHO, Rodolfo. Novo curso de direito civil, vol. VI: direito de família - as famílias em perspectiva constitucional. São Paulo: Saraiva, 2011.

GILISSEN, John. Introdução histórica ao direito. 2. ed. Lisboa: Calouste Gulbenkian, 1995.

HIRONAKA, Giselda Maria Fernandes Novaes. Os contornos jurídicos da responsabilidade afetiva na relação entre pais e flhos além da obrigação legal de caráter material. In: HIRONAKA, Giselda Maria Fernandes Novaes (Coord.). A outra face do Poder Judiciário. Decisões inovadoras e mudanças de paradigmas, vol. I. Belo horizonte: Del Rey; São Paulo: EPD, 2005.

LOBO. Paulo. Direito civil: famílias. 4. ed. São Paulo: Saraiva, 2011.

LOBO. Paulo. Direito de família e os princípios constitucionais. In: PEREIRA, Rodrigo da Cunha. Tratado de direito das famílias. Belo Horizonte : IBDFAM, 2015.

MADALENO, Rolf. Curso de direito de família. 5. ed. rev., atual. e ampl. Rio de Janeiro: Forense, 2013.

MILANESE, Pablo. El moderno derecho penal y la quiebra del principio de la intervención mínima. Revista do Instituto dos Magistrados do Ceará. Fortaleza, n 14 , p. 303-334, jul/dez. 2003.

PEREIRA, Rodrigo da Cunha (org.) Tratado de direito das famílias. Belo Horizonte: IBDFAM, 2015.

ROCHA. Marco Túlio de Carvalho. O conceito de família e suas implicações jurídicas: teoria sociojurídica do direito de família. Rio de Janeiro: Elsevier, 2009.

SEBASTIÃO FILHO, Jorge. Interceptação telefônica como medida cautelar probatória nos delitos econômicos. Curitiba: Juruá, 2012.

SILVA SÁNCHEZ, Jesus-Maria. A expansão do Direito Penal: aspectos da política criminal nas sociedades pós industriais. Tradução de Luiz Otávio de Oliveira Rocha. 3 ed. rev. atual. São Paulo: Revista dos Tribunais, 2013.

TARTUCE, Flavio. Novos princípios do direito de família brasileiro. In: TEIXEIRA. Ana Carolina Brochado; RIBEIRO. Gustavo Pereira Leite (Coord.). Manual de direito das Famílias e das sucessões. Belo Horizonte: Del Rey; Mandamentos, 2008.

TAVARES DA SILVA, Regina Beatriz. Cuidado de pai e de mãe é dever de natureza objetiva. Revista Consultor Jurídico, São Paulo: Dublê Editorial, 4 de maio de 2012. Disponível em: http://www.conjur.com.br/2012-mai-04/regina-beatriz-cuidado-pai-maedever-natureza-objetiva\#author. Acesso em: 04 abr. 2016. 